\title{
Complications in the Assignment of 14 and 28 Da Mass Shift Detected by Mass Spectrometry as in Vivo Methylation from
}

\section{Endogenous Proteins}

\author{
Sung Yun Jung ${ }^{\dagger}$, Yehua Li†, Yi Wang ${ }^{\dagger}$, Yue Chen $\ddagger$, Yingming Zhao $\ddagger$, and Jun Qin ${ }^{\star}, \dagger$ \\ Center for Molecular Discovery, Verna and Mars McLean Department of Biochemistry and \\ Molecular Biology, Department of Molecular and Cellular Biology, Baylor College of Medicine, \\ Houston, Texas 77030, and Department of Biochemistry, University of Texas Southwestern \\ Medical Center at Dallas, Dallas, Texas 75390
}

\begin{abstract}
Identification of protein methylation sites typically starts with database searching of MS/MS spectra of proteolytic digest of the target protein by allowing addition of 14 and $28 \mathrm{Da}$ in the selected amino acid residues that can be methylated. Despite the progress in our understanding of lysine and arginine methylation, substrates and functions of protein methylation at other amino acid residues remain unknown. Here we report the analysis of protein methylation for p53, SMC3, iNOS, and MeCP2. We found that a large number of peptides can be modified on the lysine, arginine, histidine, and glutamic acid residues with a mass increase of 14 or $28 \mathrm{Da}$, consistent with methylation. Surprisingly, a majority of which did not demonstrate a corresponding mass shift when cells were cultured with isotope-labeled methionine, a precursor for the synthesis of $S$ adenosyl-L-methionine (SAM), which is the most commonly used methyl donor for protein methylation. These results suggest the possibility of either exogenous protein methylation during sample handling and processing for mass spectrometry or the existence of SAM-independent pathways for protein methylation. Our study found a high occurrence of protein methylation from SDS-PAGE isolated endogenous proteins and identified complications for assigning such modifications as in vivo methylation. This study provides a cautionary note for solely relying on mass shift for mass spectrometric identification of protein methylation and highlights the importance of in vivo isotope labeling as a necessary validation method.
\end{abstract}

There exists the potential for widespread protein methylation, as a large number of methyltransferases and demethylases are coded in the genome of eukaryotic cells. ${ }^{1,2}$ Eight amino acid residues, including arginine $(\mathrm{R})$, lysine $(\mathrm{K})$, aspartate $(\mathrm{D})$, glutamate $(\mathrm{E})$, histidine $(\mathrm{H})$, asparginine $(\mathrm{N})$, glutamine $(\mathrm{Q})$, and cysteine $(\mathrm{C})$ can be methylated. ${ }^{3}$ While methylation of $\mathrm{K} / \mathrm{R}$ has been found in histones and transcriptional factors and is an important mechanism for epigenetic regulation, methylated substrates and their enzymes of other methylated residues remain largely unknown. For example, D-methylation is reported in both eukaryotic and prokaryotic cells, but the number of known substrates is limited; ${ }^{4} \mathrm{a}$ definitive evidence for E-methylation in eukaryotes is missing. Functional characterization of protein methylation at diverse amino acid residues awaits information of substrate proteins and their modification sites.

\footnotetext{
*To whom correspondence should be addressed. jqin@bcm.tmc.edu. Fax: (713) 796-9438. Tel: (713) 798-1507.

†aylor College of Medicine.

\#University of Texas Southwestern Medical Center at Dallas.

SUPPORTING INFORMATION AVAILABLE

Additional information as noted in text. This material is available free of charge via the Internet at http://pubs.acs.org.
} 
Mass spectrometry (MS) is the method of choice for the identification of protein posttranslational modifications (PTM) including methylation. ${ }^{5-9}$ A methylated peptide derived from protein enzymatic digests is typically identified by the characteristic multiple $14 \mathrm{Da}$ mass shift (e.g., $14 \mathrm{Da}$ for monomethylation, $28 \mathrm{Da}$ for dimethylation, and $42 \mathrm{Da}$ for trimethylation). The methylation site is then pinpointed from the MS/MS spectrum, typically through database searching, allowing methylation of the target amino acid residues (e.g., K, $\mathrm{R}, \mathrm{H}, \mathrm{D}$, and $\mathrm{E})$.

Recent advancement in MS, for example, the increased sensitivity of the LTQ mass spectrometer, allows the facile identification of PTM sites. PTMs that are of low stoichiometry have become easier to detect. Here we report the mass spectrometric analysis of protein methylation of four proteins, including the tumor suppressor p53, structure maintenance of chromosome 3 (SMC3), inducible nitric oxide synthase (iNOS), and methyl $\mathrm{CpG}$ binding protein 2 (MeCP2). This study identified diverse methylated residues including $\mathrm{K}, \mathrm{R}, \mathrm{H}$, and $\mathrm{E}$ in these proteins. To confirm in vivo protein methylation, we used stable isotope-labeled methionine (Met), a precursor for the synthesis of $S$-adenosyl-L-methionine (SAM), which is the most commonly used methylation donor, to label the methylated substrate proteins. Surprisingly, most of the K/R/H/E-methylated sites could not be labeled, evidenced by no corresponding mass increase of the modified peptides. The results suggest that either methylation reactions of p53, SMC3, iNOS, and MeCP2 use a novel endogenous pathway that is SAM-independent or occur exogenously. Taken together, our study suggests the high occurrence of protein methylation, provides a cautionary note for solely relying on mass shift for mass spectrometric identification of protein methylation, and highlights the importance of in vivo isotope labeling as a necessary validation method for protein methylation.

\section{EXPERIMENTAL SECTION}

\section{Cell Culture, Metabolic Labeling, and Protein Isolation}

HeLa cells, HEK293T cells, Flag-HA-p53 expressing stable H1299, and RAW cells were maintained in Dulbecco's modified Eagle's medium (DMEM) in 10\% FBS. These cells were grown in either $\mathrm{CD}_{3}$-methionine, or ${ }^{13} \mathrm{CH}_{3}$-methionine (Cambridge Isotope Lab), or ${ }^{13} \mathrm{CD}_{3}$-methionine (Sigma) (30 mg/L) substituted DMEM for more than six generations.

Cells were generally lysed in lysis buffer (25 mM Tris, pH 7.8, 1 mM EDTA, $150 \mathrm{mM}$ $\mathrm{NaCl}$, and $0.5 \% \mathrm{NP}-40$ ) with sonication. The lysate was centrifuged at $4{ }^{\circ} \mathrm{C}$ for $30 \mathrm{~min}$ at $100000 \mathrm{~g}$. The supernatant was collected and immunoprecipitated using anti-SMC3-antibody (BL5589, Bethyl laboratory), anti-iNOS-antibody (06-573, Upstate), or M2 antibody (Sigma) for Flag-HA-epitope tagged p53. RAW cells were treated with lipopolysaccharide (100 ng/mL, Sigma) and mouse INF- $\gamma$ (10 unit/mL, Sigma) to activate iNOS. MeCP2 was purified from MeCP2 overexpressed HEK293T cells according to procedures described previously. ${ }^{10}$

\section{Peptide Analysis with Mass Spectrometry}

In-gel digestion was carried out as described before. ${ }^{11}$ For nano-HPLC/MS/MS analysis, extracted peptides were dissolved in $20 \mu \mathrm{L}$ of $5 \%$ methanol $/ 95 \%$ water $/ 0.1 \%$ formic acid solution and injected into the Surveyor HPLC system (ThermoFinnigan) using an autosampler. A $100 \mathrm{~mm} \times 75 \mu \mathrm{m}, \mathrm{C} 18$ column $(5 \mu \mathrm{m}, 300-\AA$ pore diameter, PicoFrit, New Objective) with mobile phases of A ( $0.1 \%$ formic acid in water) and B $(0.1 \%$ formic acid in methanol) was used with a gradient of 5-95\% of mobile phase B over 15 min followed by $95 \% \mathrm{~B}$ for $5 \mathrm{~min}$ at a flow rate of $200 \mathrm{~nL} / \mathrm{min}$. Peptides were directly eletrosprayed into the mass spectrometer (Finnigan LTQ, ThermoFinnigan) using a nanospray source. LTQ were operated in the data-dependent mode acquiring fragmentation spectra of the top 20 strongest 
ions. For vMALDI-LTQ (Finnigan LTQ, ThermoFinnigan) analysis, extracted histone tryptic peptides were dissolved in 50\% AcCN solution and DHB was used as a matrix.

MS/MS spectra were searched against a modified NCBI protein reference database using BioWorks database search engine (BioWorksBrowser ver 3.2, Thermo Electron). Mass change is incorporated for methionine according to the isotope and oxidation, and arginine, lysine, histidine, glutamic acid and aspartic acid are allowed for methylation. The missed cleavage site for trypsin digestion was set as three. Candidate methylated peptides were identified with stringent BioWorksBrowser filtering criteria: peptide probability $>5 \times 10^{-5}$ and Xcorr score $>4.0$ for $3+$ ions and 2.2 for $2+$ ions. These candidate identifications were examined manually and compared with nonmethylated peptides that all peaks must be assigned, and all fragment ions containing the methylation sites have the corresponding mass shift from the nonmethylated fragments.

\section{In Vitro E-Methylation of Bovine Serum Albumin (BSA)}

BSA was resolved in SDS-PAGE and stained with ProtoBlue Safe staining kit (National Diagnostics) according to the manufacturer's instruction. Methanol was excluded in the buffer. The gel band containing $0.2 \mathrm{pmol}$ of BSA was sliced into small pieces and destained with $25 \mathrm{mM}$ ammonia bicarbonate solution (methanol/water, 50:50 v/v), followed by washing in an acidic buffer (acetic acid/methanol/water, 10:50:40, v/v/v) three times, with 1 $\mathrm{h}$ each time, and in water two times, with 20 min each time. The gel pieces were then dehydrated in $100 \%$ acetonitrile and dried in a SpeedVac (ThermoFisher). The dried gels was added, $\sim 150 \mathrm{ng}$ of porcine modified trypsin (Promega) in $50 \mathrm{mM}$ ammonia bicarbonate, and incubated overnight at $37^{\circ} \mathrm{C}$. Tryptic peptides were sequentially extracted from the gel pieces by 50\% acetonitrile buffer (acetonitrile/water/trifluoroacetic acid (TFA), 50:45:5, v/v/ v) and $75 \%$ acetonitrile buffer (acetonitrile/water/TFA, 75:24:1, v/v/v). The extracted peptides were pooled, dried in a SpeedVac, and desalted using a $\mu$-C18 Ziptip (Millipore) prior to HPLC/MS/MS analysis.

\section{Non-Methanol Protocol for Processes of BSA}

The same amount of BSA was in-gel digested with the same procedure described above except that methanol used in each buffers was replaced with ethanol as a control sample for non-methanol in-gel digestion.

\section{Methanol-Free Nano-HPLC Mass Spectrometry Analysis}

HPLC/MS/MS of the tryptic peptides from BSA were carried out according to a procedure previously described. ${ }^{12}$ Methanol was excluded as a cosolvent in the HPLC buffers. Briefly, The peptide solution in buffer A ( $2 \%$ acetonitrile $/ 97.9 \%$ water/ $0.1 \%$ acetic acid, v/v/v) was manually injected and separated in a capillary HPLC column (50 mm length $\times 75 \mu$ m i.d., 5 $\mu \mathrm{m}$ particle size, $300 \AA$ pore diameter) packed in-house with Luna C18 resins. Peptides were eluted from the column with a 60 -min gradient of $5-80 \%$ buffer B (90\% acetonitrile/9.9\% water $/ 0.1 \%$ acetic acid, $v / v / v$ ) in buffer A. The eluted peptides were electrosprayed directly into the LCQ DECA XP ion trap mass spectrometer. Normalized energy for collisioninduced dissociation is 35\%. Each MS/MS spectrum was obtained by averaging three microscans with maximum injection time of $110 \mathrm{~ms}$ for each microscan. The MS/MS spectra were acquired in a data-dependent mode, such that the masses and fragmentation patterns of the three strongest ions in each MS scan were determined. 


\section{RESULTS AND DISCUSSION}

\section{Mass Spectrometric Detection of Protein Methylation of Endogenous Proteins}

To map protein modification sites, endogenous proteins were immunopurified and resolved in SDS-PAGE. The target proteins were in-gel digested with trypsin, and the peptides were analyzed using nano-HPLC/LTQ mass spectrometry for protein identification and mapping of PTM sites. During routine analysis of PTMs of proteins, we found that many tryptic peptides have mass increase of 14 or $28 \mathrm{Da}$, which is consistent with mono- or dimethylation. We show here four proteins, in which $\mathrm{K}, \mathrm{R}, \mathrm{E}$, and $\mathrm{H}$ residues were detected by mass spectrometry to be consistent with methylation.

Lysine/Arginine Methylation of SMC3-SMC3 is a component of the human cohesin complex that plays an important role in connecting sister chromatids before mitosis and segregation of the sister chromatid into two daughter cells. ${ }^{13-15}$ Human cohesin complex was purified from HeLa cells using SMC3 antibody (Figure 1A). HPLC/MS/MS analysis identified six arginine methylation sites and seven lysine methylation sites in the SMC3 protein (Table 1). For example, we detected both the unmodified form of the peptide ${ }^{986}$ ALDQFVNFSEQK ${ }^{997}(\mathrm{~m} / \mathrm{z} 714.00$ with the HPLC retention time of $33.38 \mathrm{~min}$ (Figure 1E)) and its modified form $(\mathrm{m} / z 721.37$ with HPLC retention time of $34.06 \mathrm{~min}$ (Figure 1F). The major difference of the two spectra is +14 mass shifts that are present in almost all the y ions of the modified peptide (Figure 1F). A comparison of the two MS/MS spectra conclusively localized the modification site to K997 of SMC3.

Arginine/Lysine/Glutamic Acid Methylation of iNOS-iNOS is an effector protein in the immune system that produces nitric oxide in microphage in response to bacteria infection. ${ }^{16,17}$ To analyze PTMs of iNOS, we immunoprecipitated iNOS from the cytoplasmic fraction of RAW cells after stimulation with lipopolysaccharide and INF- $\gamma$ (Figure 1B) and subjected iNOS for trypsin digestion. Analysis of the tryptic peptides identified peptides with a modification on the $\mathrm{R}, \mathrm{K}$, and $\mathrm{E}$ residues that results in $14 \mathrm{Da}$ mass increases, suggesting methylation (Table 1).

Monomethylation of R1118 in the peptide ${ }^{1105}$ LIQSPEPLDL-NR $* 1118$ was identified by a comparison of the unmodified form (Figure 2A) with the modified form (Figure 2B). The observation of the $303.3 \mathrm{~m} / \mathrm{z}$ peak (assigned as $\mathrm{y} 2+14 \mathrm{Da}$ ) and the $1220.5 \mathrm{~m} / \mathrm{z}$ peak (assigned as b11) (Figure 2B) conclusively located the modification at R1118. Interestingly, the same peptide was also observed to be methylated at E1110 from the same HPLC/MS/ MS run (Figure 2C). E-Methylation has been reported in bacteria and is known to be important for chemotaxis, ${ }^{18-20}$ but its occurrence in eukaryotes has not been conclusively established. The O-methylation of the D-isoaspartic residue is established to be a protein repair mechanism. ${ }^{21}$ Mass increase of $14 \mathrm{Da}$ of D/E residues in the PCNA protein has been reported, suggesting O-methylation, ${ }^{22}$ but $\mathrm{D} / \mathrm{E}$-methylation in eukaryotes has not been carefully examined in the past.

To evaluate the extent of D/E-methylation, we reanalyzed our MS/MS data sets from nanoHPLC/MS/MS of more than 50 SDS-PAGE isolated endogenous proteins, which are mainly nuclear proteins involved in DNA damage response, DNA repair, and transcription regulation. Database search and subsequent manual verification found that many peptides were modified at $\mathrm{E}, \mathrm{K}$, and $\mathrm{R}$, resulting in 14 or 28 Da mass increases in their corresponding peptides and fragment ions. Fifty-three unique methylated peptides were observed from our MS/MS data set (Supporting Information (SI) Table S-1). Our observation suggests that protein methylation may be more widespread than previously appreciated. 


\section{Protein Methylation in Overexpressed Proteins}

Purification of ectopically overexpressed proteins has now become a common method for identification of protein complex as well as protein PTMs. In the following experiments, we isolated two overexpressed transcriptional factors, human p53 and MeCP2, and analyzed their methylation patterns.

Protein Methylation of p53-The tumor suppressor protein p53 modulates cell cycle arrest, senescence, and apoptosis. Diverse PTMs of p53 were identified previously, including phosphorylation, methylation, acetylation, ubiquitination, and sumoylation. ${ }^{23} \mathrm{R} /$ $\mathrm{K}$-methylation of $\mathrm{p} 53$ led to transcription repression by recruiting methylation-dependent corepressor protein complexes containing Sin3A, Brahma, and histone deacetylases to p53 target genes. ${ }^{24,25}$ Two lysine methylation sites (K370 and K372) of p53 were identified, ${ }^{26,27}$ in which the Set9-mediated methylation of K372 inhibits Smyd2-mediated methylation of $\mathrm{K} 370$, providing regulatory cross talk between protein methylation. ${ }^{28}$

Our analysis of tryptic peptides from the purified p53 (Figure 1C) identified H115 as monomethylated, based on $14 \mathrm{Da}$ increase on the b5 ion $(\mathrm{m} / \mathrm{z}$ 582.3) and y6 ion $(\mathrm{m} / \mathrm{z}, 614.3)$ (Figure 3B). Interestingly, methylation of $\mathrm{H} 73$ of actin is the only example reported up to date for histidine methylation. ${ }^{29,30} \mathrm{We}$ also found 12 other methyation sites, including 4 methylated R and 8 methylated E (Table 1). However, we did not detect two previously reported methylated lysines (K370 and K372), ${ }^{31,32}$ most likely because the tryptic peptide containing these two lysines is too short to be detected by the mass spectrometer (R/ AHSSHLK ${ }^{370} / \mathrm{SK}^{372}$ ). Among the $12 \mathrm{R}$ and E methylation sites identified, $3 \mathrm{R}$ (R110, R209, R214) and 4 E (E11, E224, E295, E326) are reported to be mutated in various cases of cancer. ${ }^{33,34}$ If methylation of these residues turns out to be a regulatory mechanism for p53 function, our finding suggests that protein methylation will have a profound impact on p53 related cancer.

\section{Protein methylation of MeCP2}

$\mathrm{MeCP} 2$ is a member of the methyl-DNA-binding protein family, which binds DNA containing methylated $\mathrm{CpG}$ dinucleotides ${ }^{35}$ and acts as a methylation dependent transcription repressor by recruiting transcriptional corepressor protein complexes. Mutations in the MeCP2 gene are found in the majority of patients with Rett Syndrome, a severely disabling X-linked progressive neurological disorder and a leading cause of mental retardation in females. ${ }^{36}$ It has been reported that MeCP2 is post-translationally modified and such modifications are important for $\mathrm{MeCP} 2$ function. For example, MeCP2 is phosphorylated in a neuronal activity-dependent manner and such phosphorylation is required for depression of BDNF transcription. ${ }^{37} \mathrm{HPLC} / \mathrm{MS} / \mathrm{MS}$ analysis of the overexpressed MeCp2 (Figure 1D) revealed three methylated E residues (E 258, 298, 448) as well as two methylated $\mathrm{K}$ residues (K210, K119) (Table 1). K210 is identified as a mutation site in several cases of Rett syndrome, indicating that the inability to methylate K210 may be a cause for the Rett syndrome.

\section{In Vivo Labeling of Proteins with Stable Isotope-Labeled Methionine}

To confirm in vivo protein methylation, we carried out stable isotope labeling experiment using heavy isotope-labeled Met in tissue cultured cells. ${ }^{38-40}$ Methyltransferases use SAM as a methyl donor for protein methylation, and in eukaryotic cells, SAM is produced from Met. When cells are cultivated with isotope-labeled Met, in which the side chain of Met is labeled with the $\mathrm{S}^{-13} \mathrm{CH}_{3}$ group, the $13 \mathrm{CH}_{3}$ group is incorporated into $\mathrm{SAM}$ and subsequently transferred to the methylated substrate proteins. Thus, incorporation of isotopic ${ }^{13} \mathrm{CH}_{3}$ into methylated residues provides the definitive evidence for in vivo protein methylation. 
We cultured HeLa and HEK 293T cells with regular Met (mainly ${ }^{12} \mathrm{CH}_{3}$ ), ${ }^{13} \mathrm{CH}_{3}$-Met, or $\mathrm{CD}_{3}$-Met supplemented media. Complete metabolic labeling was confirmed by mass spectrometry analysis (SI, Figure S-1). To test the biological availability of isotope-labeled Met, we examined methylation of histone $\mathrm{H} 3$ at K79, a well-established monomethylated substrate protein..$^{41}$ The core histones were isolated by acid extraction accordingly to a procedure described previously ${ }^{42}$ and resolved in SDS-PAGE. K79 methylation of H3 from the labeled cells was confirmed by nano-HPLC/MS/MS of the H3 tryptic peptide with a mass shift of 15 and $17 \mathrm{Da}$ from cells cultured with ${ }^{13} \mathrm{CH}_{3}$ - and $\mathrm{CD}_{3}$-Met, respectively. Such 15 and $17 \mathrm{Da}$ increase in mass corresponds to the addition of ${ }^{13} \mathrm{CH}_{3}$ and $\mathrm{CD}_{3}$ on $\mathrm{K} 79$ of histone $\mathrm{H} 3$ (SI, Figure S-2). In addition, we found methylation of $\mathrm{H} 73$ in actin that results in 17 Da mass increases in cells that were dosed with $\mathrm{CD}_{3}$-Met (SI, Figure S-3) These results confirmed that in vivo methylated proteins are isotopically labeled under our experimental conditions.

Next, we tried to confirm in vivo methylation of SMC3, iNOS, and MeCP2. Cells were labeled with either ${ }^{13} \mathrm{CH}_{3}$-Met or $\mathrm{CD}_{3}$-Met. Surprisingly, we did not detect labeled peptides with mass increase of 15 and $17 \mathrm{Da}$, or 30 and $34 \mathrm{Da}$ (corresponding to dimethylated peptides); instead, we detected modified peptides with $14 \mathrm{Da}$ or $28 \mathrm{Da}$ mass increase from endogenous SMC3, iNOS, and MeCP2 (Figure 4, and Figures S-4-S6, SI), indicating that these modified peptides were not derived from SAM that is synthesized from the labeled Met. For example, in the ${ }^{13} \mathrm{CH}_{3}$-Met-labeled MeCP2 proteins, a $14 \mathrm{Da}$, but not a $15 \mathrm{Da}$ shift in K450 was observed for the $m / z 673.2$ peptide ${ }^{435}$ TQPAVATAATAAEK ${ }^{* 450}$. The $14 \mathrm{Da}$ increase on K450 was evidenced from the $290.3 \mathrm{~m} / \mathrm{z}$ peak $\left(\mathrm{y}^{2}+14 \mathrm{Da}\right)$ and then $1183.3 \mathrm{~m} / \mathrm{z}$ peak (unmodified b ${ }^{13}$ ) (Figure 4A, B). Similarly, we found 14 Da increase rather than $15 \mathrm{Da}$ increase on Arg 236 in the SMC3 peptide of ${ }^{222}$ ALEYTIYN-QELNETR ${ }^{2} 236$ derived from $\mathrm{CD}_{3}$-Met-labeled HeLa cells (SI, Figure S-4). Likewise, we observed $14 \mathrm{Da}$ increase in two peptides of overexpressed human iNOS protein from the ${ }^{13} \mathrm{CD}_{3}$-Met-labeled RAW cell. E1108 was found to have a mass shift of $14 \mathrm{Da}$ in the peptide of ${ }^{1105} \mathrm{LNEE}^{*} \mathrm{QVEDYFFQLK}{ }^{1118}$; H708 was found to have a mass shift of $14 \mathrm{Da}$ in the peptide of ${ }^{696}$ LYTSNVTWDPH*HYR ${ }^{711}$ (SI, Figures S-5 and S-6). The finding that H708 does not exhibit the corresponding isotope mass shift is surprising as histidine in actin was observed to do so.

Isotope-labeled SAM was used as a donor for methylation reaction, as we did observe a tryptic peptide, ${ }^{156}$ VGDTSLDPND-FDFTVTGR ${ }^{175}$, from the overexpressed MeCP2 that shows a 15 Da mass increases in R175, demonstrating monomethylation of R175 (Figure 5). Therefore, SAM is used as a methyl donor and MECP2 is methylated under our experimental conditions. The sequence flanking ${ }^{174} \mathrm{GRG}^{176}$ conforms to the methylation consensus of the two major protein arginine methyltransferase, PRMT1 (type I) and PRMT5 (type II), which preferentially methylates arginines in the RG-rich clusters. ${ }^{43}$

\section{Glutamic Acid Can Be Methylated by Methanol-Containing Buffer during Gel Destaining in Vitro}

The SILAC experiment strongly suggests the possibility that methylation can happen in vitro. Because methanol is extensively used in SDS-PAGE and subsequent sample preparation for mass spectrometry analysis, we suspect that some of the methylation may happen during these processes. To answer whether methanol can act as an in vitro methyl donor for D/E methylation, we carried out in-gel digestion of BSA with or without methanol. We used a gel-staining kit (ProtoBlue Safe, National Diagnostics) that does not contain methanol in its solutions, to prevent in vitro methylation before protein digestion, and analyzed BSA tryptic digests in HPLC buffers that do not contain methanol. To improve the sensitivity, we employed selective ion monitering in the MS/MS mode, which is to isolate ions based on their theoretical $\mathrm{m} / \mathrm{z}$ values and acquire MS/MS spectra. We selected 
10 peptides, each of which contains at least one $\mathrm{D} / \mathrm{E}$, and their hypothetical methylated form.

Analysis of HPLC/MS/MS of BSA peptides digested with modified non-methanol protocol identified 31 peptides and zero D/E-methylated peptide. On the other hand, 29 peptides and 4 E-methylated peptides (SI, Table S-2, Figure S-7) were identified from BSA tryptic peptides generated using standard methanol-containing protocol. The intensities of the 29 unmodified peptides shared by the two analyses were comparable, suggesting that the absence of E-methylated peptides is not caused by the difference of in-gel digestion efficiency. These data demonstrate that glutamate could be methylated in vitro during mass spectrometric sample processing in destaining of the SDS-PAGE gel in methanol-containing buffer.

Taking both the SILAC SAM labeling and in vitro BSA methylation results, the failure to confirm methylation by in vivo SAM labeling could be explained by two possibilities. First, methyl donors other than SAM might be used for the methylation reactions in cells. For example, folate (methyl-tetrahydrofolate) was known to be another methyl donor for methionine synthesis. ${ }^{44}$ Alternatively, methylation happens exogenously during sample handling and processing. During SDS-PAGE and subsequent staining/destaining, large amounts of methanol and acidic acid are used. The side chains of D/E can be methylated by the nucleophilic addition of the $\mathrm{OH}$ group of methanol to the protonated $\mathrm{COOH}$ group. On the other hand, under the same condition, the side chains of $\mathrm{H}, \mathrm{K}$, and $\mathrm{R}$ are protonated and can neither attack the methyl group of methanol nor be attacked by the $\mathrm{OH}$ group of methanol. Thus, exogenous methylation is likely for the D/E residue, but is harder to explain for $\mathrm{H}, \mathrm{K}$, and $\mathrm{R}$ residues when acidic acid and methanol are used. Thus, protein methylation as detected by mass spectrometry might happen both in vitro and in vivo, and careful verification is required to pinpoint the origin of methylation.

\section{CONCLUSIONS}

Improvement in sensitivity of mass spectrometry has enabled us to find protein modifications of low stoichiometry. This raises a question as to whether the observation of a mass increase from a peptide and subsequent MS/MS to pinpoint the modification site is sufficient to conclude that the residue is modified in vivo and whether another validation procedure is necessary. High occurrence of lysine formylation from silver-stained gels has been reported. ${ }^{45}$ Here we report the observation that peptides containing K, R, H, and E residues are modified with the addition of 14 or $28 \mathrm{Da}$, suggesting methylation. However, we failed to observe corresponding isotope labeling of these putative methylated proteins with isotope-labeled Met that is the precursor for SAM, the most widely used methyl donor in cells. This is attributed to either exogenous methylation reaction or the existence of additional methylation donors other than SAM. Our findings provide a cautionary note for protein methylation identified solely by mass spectrometry and point to the need for other independent verification, preferably by isotopic labeling, if the methylation reaction mechanism is clear. This precaution applies to not only poorly understood E-methylation reaction in mammalian system but also well-established in vivo $\mathrm{N}$-methylation ( $\mathrm{K}$ and $\mathrm{R}$ ). In the case of D/E-methylation, the artifact may be minimized by using buffer systems without methanol.

\section{Supplementary Material}

Refer to Web version on PubMed Central for supplementary material. 


\section{Acknowledgments}

This work is supported in part by NIH CA84199 (J.Q.) and Welch Foundation Q-1670 (J.Q.) and DODW81XWH-04-1-0137 (Y.W.). We thank Drs. Huda Zoghbi, Tony Eissa, and Wei Gu for the samples of MeCP2, iNOS, and 533 .

\section{References}

1. Cheng X, Zhang X. Mutat Res 2007;618:102-15. [PubMed: 17374386]

2. Shi Y, Whetstine JR. Mol Cell 2007;25:1-14. [PubMed: 17218267]

3. Walsh CT, Garneau-Tsodikova S, Gatto GJ Jr. Angew Chem, Int Ed 2005;44:7342-72.

4. Clarke S. Curr Opin Cell Biol 1993;5:977-83. [PubMed: 8129951]

5. Kim SC, Sprung R, Chen Y, Xu Y, Ball H, Pei J, Cheng T, Kho Y, Xiao H, Xiao L, Grishin NV, White M, Yang XJ, Zhao Y. Mol Cell 2006;23:607-18. [PubMed: 16916647]

6. Mann M, Jensen ON. Nat Biotechnol 2003;21:255-61. [PubMed: 12610572]

7. Rappsilber J, Friesen WJ, Paushkin S, Dreyfuss G, Mann M. Anal Chem 2003;75:3107-14. [PubMed: 12964758]

8. Boisvert FM, Cote J, Boulanger MC, Richard S. Mol Cell Proteomics 2003;2:1319-30. [PubMed: 14534352]

9. Brame CJ, Moran MF, Broom-Cerajewski LD. Rapid Commun Mass Spectrom 2004;18:877-81. [PubMed: 15095356]

10. Allis CD, Glover CV, Gorovsky MA. Proc Natl Acad Sci USA 1979;76:4857-61. [PubMed: 291904]

11. Zhang X, Herring CJ, Romano PR, Szczepanowska J, Brzeska H, Hinnebusch AG, Qin J. Anal Chem 1998;70:2050-9. [PubMed: 9608844]

12. Chen Y, Kwon SW, Kim SC, Zhao Y. J Proteome Res 2005;4:998-1005. [PubMed: 15952748]

13. Dorsett D, Eissenberg JC, Misulovin Z, Martens A, Redding B, McKim K. Development 2005;132:4743-53. [PubMed: 16207752]

14. Watrin E, Peters JM. Exp Cell Res 2006;312:2687-93. [PubMed: 16876157]

15. Yazdi PT, Wang Y, Zhao S, Patel N, Lee EY, Qin J. Genes Dev 2002;16:571-82. [PubMed: 11877377]

16. Fang FC. J Clin Invest 1997;99:2818-25. [PubMed: 9185502]

17. Lowenstein CJ, Padalko E. J Cell Sci 2004;117:2865-7. [PubMed: 15197240]

18. Shapiro MJ, Chakrabarti I, Koshland DE Jr. Proc Natl Acad Sci USA 1995;92:1053-6. [PubMed: 7862632]

19. Terwilliger TC, Koshland DE Jr. J Biol Chem 1984;259:7719-25. [PubMed: 6330075]

20. Terwilliger TC, Wang JY, Koshland DE Jr. J Biol Chem 1986;261:10814-20. [PubMed: 3015942]

21. McFadden PN, Clarke S. Proc Natl Acad Sci USA 1982;79:2460-4. [PubMed: 6123997]

22. Hoelz DJ, Arnold RJ, Dobrolecki LE, bdel-Aziz W, Loehrer AP, Novotny MV, Schnaper L, Hickey RJ, Malkas LH. Proteomics 2006;6:4808-16. [PubMed: 16888766]

23. Bode AM, Dong Z. Nat Rev Cancer 2004;4:793-805. [PubMed: 15510160]

24. Nan X, Campoy FJ, Bird A. Cell 1997;88:471-81. [PubMed: 9038338]

25. Harikrishnan KN, Chow MZ, Baker EK, Pal S, Bassal S, Brasacchio D, Wang L, Craig JM, Jones PL, Sif S, El-Osta A. Nat Genet 2005;37:254-64. [PubMed: 15696166]

26. Chuikov S, Kurash JK, Wilson JR, Xiao B, Justin N, Ivanov GS, McKinney K, Tempst P, Prives C, Gamblin SJ, Barlev NA, Reinberg D. Nature 2004;432:353-60. [PubMed: 15525938]

27. Huang J, Perez-Burgos L, Placek BJ, Sengupta R, Richter M, Dorsey JA, Kubicek S, Opravil S, Jenuwein T, Berger SL. Nature 2006;444:629-32. [PubMed: 17108971]

28. Huang J, Perez-Burgos L, Placek BJ, Sengupta R, Richter M, Dorsey JA, Kubicek S, Opravil S, Jenuwein T, Berger SL. Nature 2006;444:629-32. [PubMed: 17108971]

29. Yao X, Nguyen V, Wriggers W, Rubenstein PA. J Biol Chem 2002;277:22875-82. [PubMed: 11940592] 
30. Cass KA, Clark EB, Rubenstein PA. Arch Biochem Biophys 1983;225:731-9. [PubMed: 6625608]

31. Chuikov S, Kurash JK, Wilson JR, Xiao B, Justin N, Ivanov GS, McKinney K, Tempst P, Prives C, Gamblin SJ, Barlev NA, Reinberg D. Nature 2004;432:353-60. [PubMed: 15525938]

32. Huang J, Perez-Burgos L, Placek BJ, Sengupta R, Richter M, Dorsey JA, Kubicek S, Opravil S, Jenuwein T, Berger SL. Nature 2006;444:629-32. [PubMed: 17108971]

33. Amikura T, Sekine M, Hirai Y, Fujimoto S, Hatae M, Kobayashi I, Fujii T, Nagata I, Ushijima K, Obata K, Suzuki M, Yoshinaga M, Umesaki N, Satoh S, Enomoto T, Motoyama S, Nishino K, Haino K, Tanaka K. Gynecol Oncol 2006;100:365-71. [PubMed: 16337994]

34. Ohgaki H, Hard GC, Hirota N, Maekawa A, Takahashi M, Kleihues P. Cancer Res 1992;52:29958. [PubMed: 1316233]

35. Lewis JD, Meehan RR, Henzel WJ, Maurer-Fogy I, Jeppesen P, Klein F, Bird A. Cell 1992;69:905-14. [PubMed: 1606614]

36. Amir RE, Van dVI, Wan M, Tran CQ, Francke U, Zoghbi HY. Nat Genet 1999;23:185-8. [PubMed: 10508514]

37. Chen WG, Chang Q, Lin Y, Meissner A, West AE, Griffith EC, Jaenisch R, Greenberg ME. Science 2003;302:885-9. [PubMed: 14593183]

38. Ong SE, Mittler G, Mann M. Nat Methods 2004;1:119-26. [PubMed: 15782174]

39. Zhu H, Pan S, Gu S, Bradbury EM, Chen X. Rapid Commun Mass Spectrom 2002;16:2115-23. [PubMed: 12415544]

40. Ong SE, Blagoev B, Kratchmarova I, Kristensen DB, Steen H, Pandey A, Mann M. Mol Cell Proteomics 2002;1:376-86. [PubMed: 12118079]

41. Zhang K, Tang H, Huang L, Blankenship JW, Jones PR, Xiang F, Yau PM, Burlingame AL. Anal Biochem 2002;306:259-69. [PubMed: 12123664]

42. Galasinski SC, Resing KA, Ahn NG. Methods 2003;31:3-11. [PubMed: 12893168]

43. Boisvert FM, Cote J, Boulanger MC, Richard S. Mol Cell Proteomics 2003;2:1319-30. [PubMed: 14534352]

44. Scott JM, Weir DG. Lancet 1981;2:337-40. [PubMed: 6115113]

45. Oses-Prieto JA, Zhang X, Burlingame AL. Mol Cell Proteomics 2007;6:181-92. [PubMed: 17138591] 

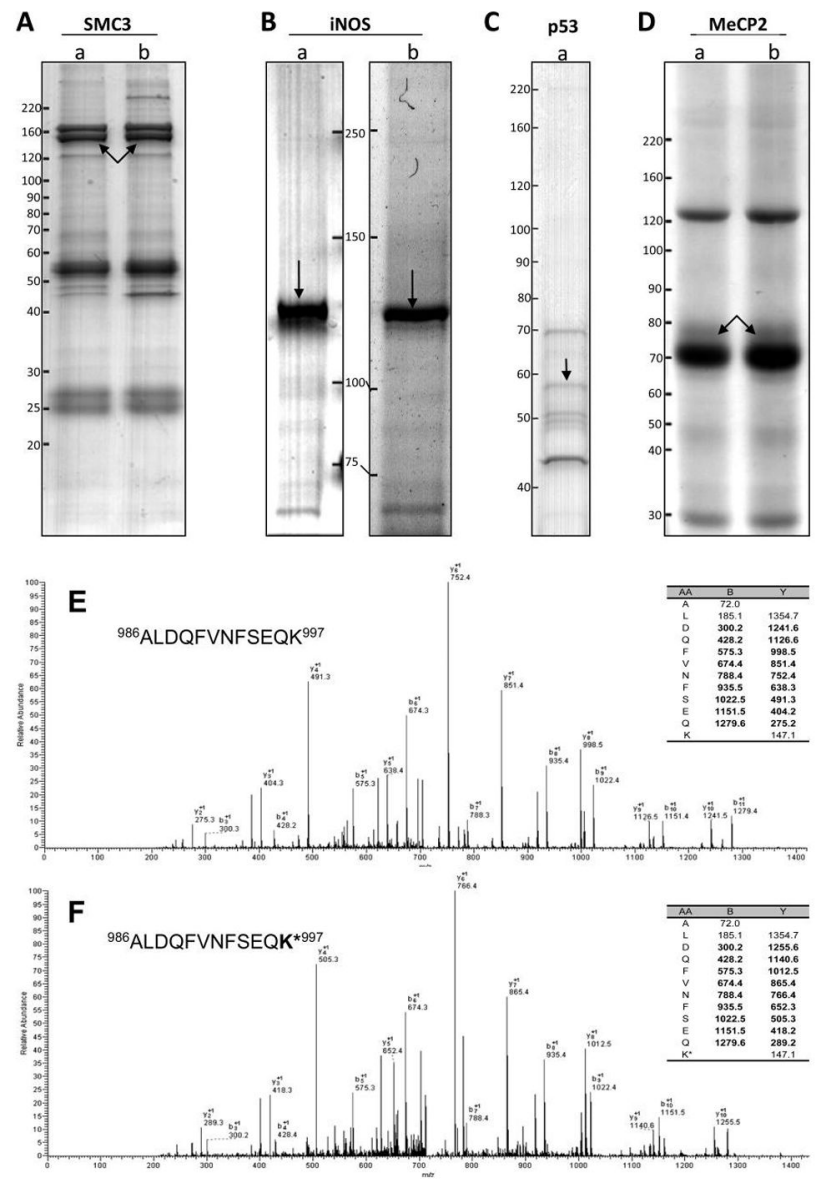

Figure 1.

SDS-PAGE of purified SMC3 (A), MeCP2 (B), iNOS (C), and p53 (D) proteins from normal medium cultured cells (a) and stable isotope-labeled methionine containing medium cultured cells (b). Protein bands for modification analysis are indicated by arrows. (E) MS/ MS spectra of an unmodified peptide, ${ }^{966}$ ALDQFVNFSEQK ${ }^{997}$ and (F) its methylated counterpart. 

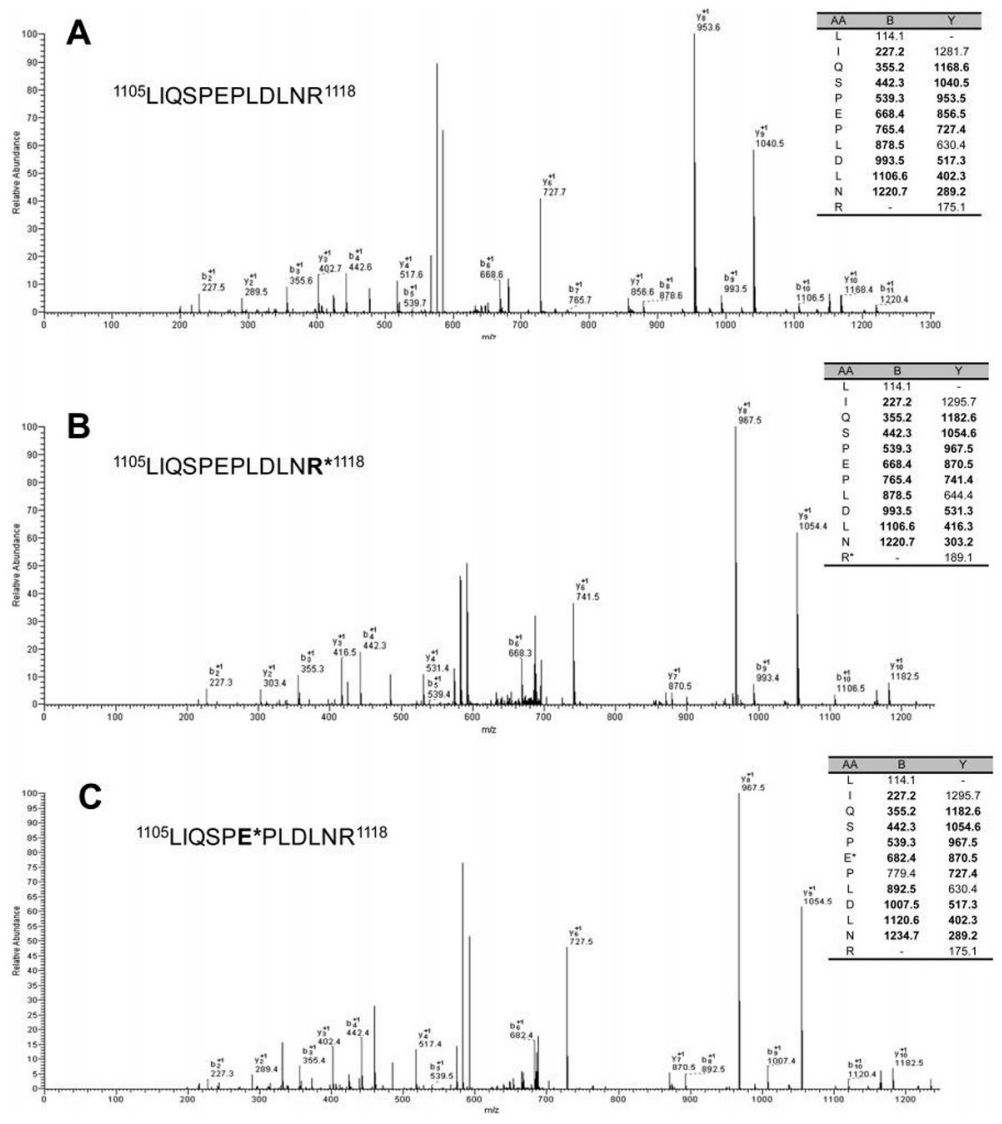

Figure 2.

Identification of arginine methylation and glutamate methylation in iNOS. (A) MS/MS spectra of (A) the unmodified peptides ${ }^{1105}$-LIQSPEPLDLNR ${ }^{1118}$, (B) its argininemethylated counterpart, and (C) its glutamate-methylated counterpart. 

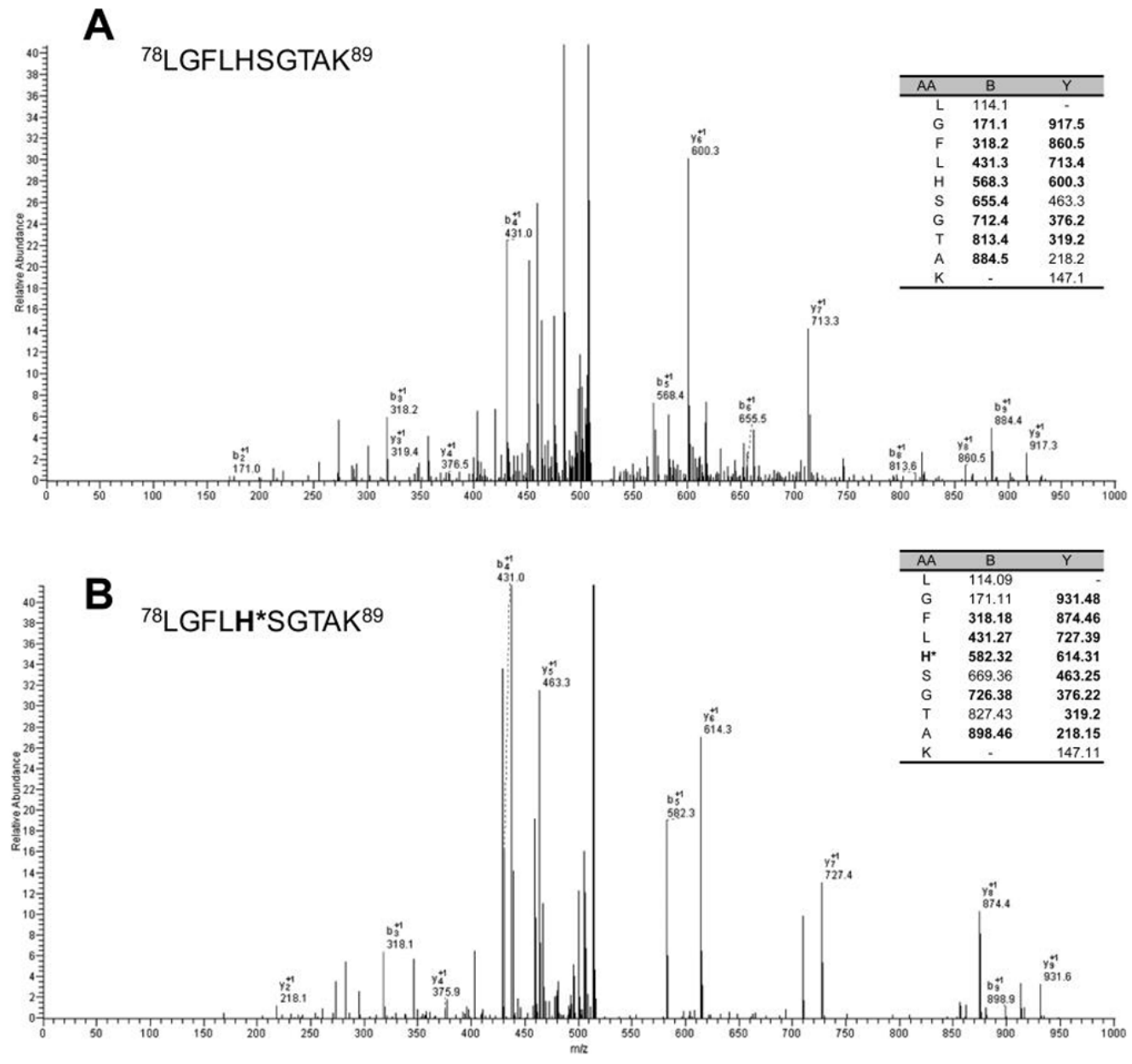

Figure 3.

Identification of histidine methylation in p53. MS/MS spectra of (A) the unmodified peptide ${ }^{111}$ LGFLHSGTAK $^{120}$ and (B) its histidine-methylated counterpart. 

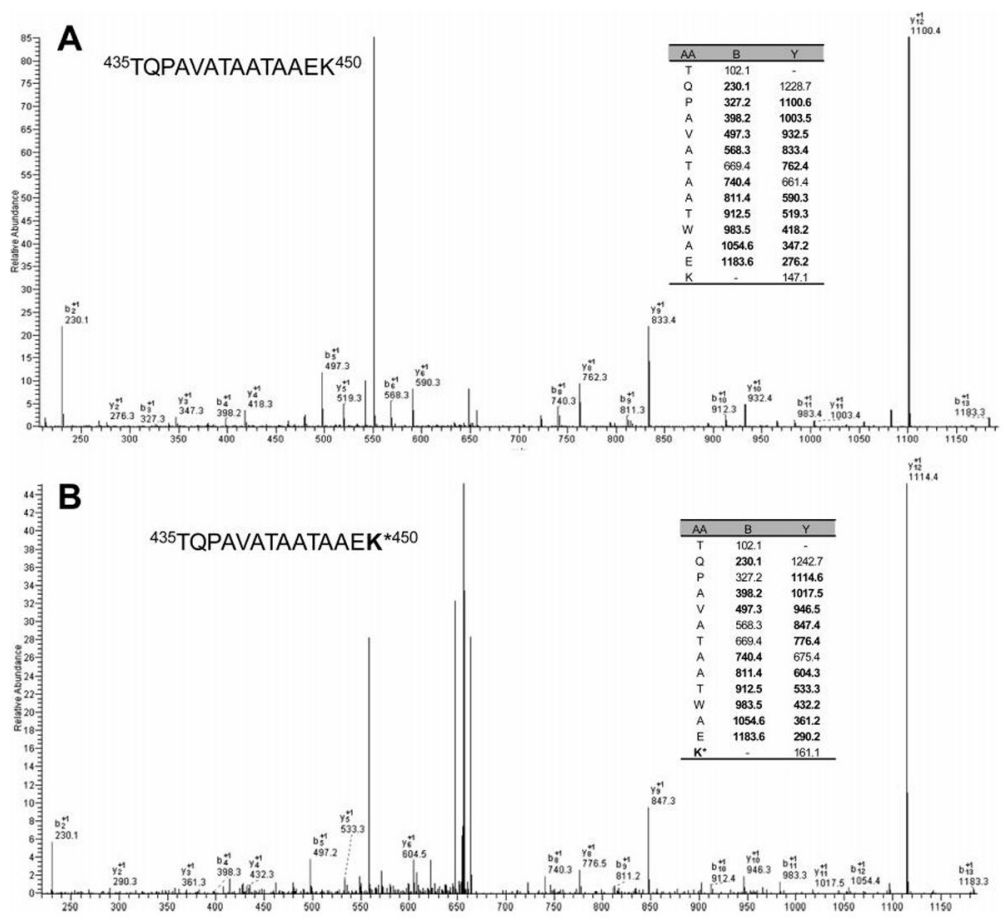

Figure 4.

Unsuccessful labeling of a MeCP2 peptide with ${ }^{13} \mathrm{CH}_{3}$-Met. Overexpressed human MeCP2 protein was purified from $13 \mathrm{CH}_{3}$-Met-labeled $293 \mathrm{~T}$ cells. (A) The MS/MS spectrum of the nonmodified MeCP2 peptide ${ }^{435}$ TQPAVATAATAAEK ${ }^{450}$. (B) The MS/MS spectrum of the methylated peptides, showing 14 Da increase in y2-y6 and y8-y11 ions. The results indicate that $\mathrm{K} 450$ is methylated but not labeled by ${ }^{13} \mathrm{CH}_{3}-\mathrm{Met}$, which would give a mass increase of $15 \mathrm{Da}$. 

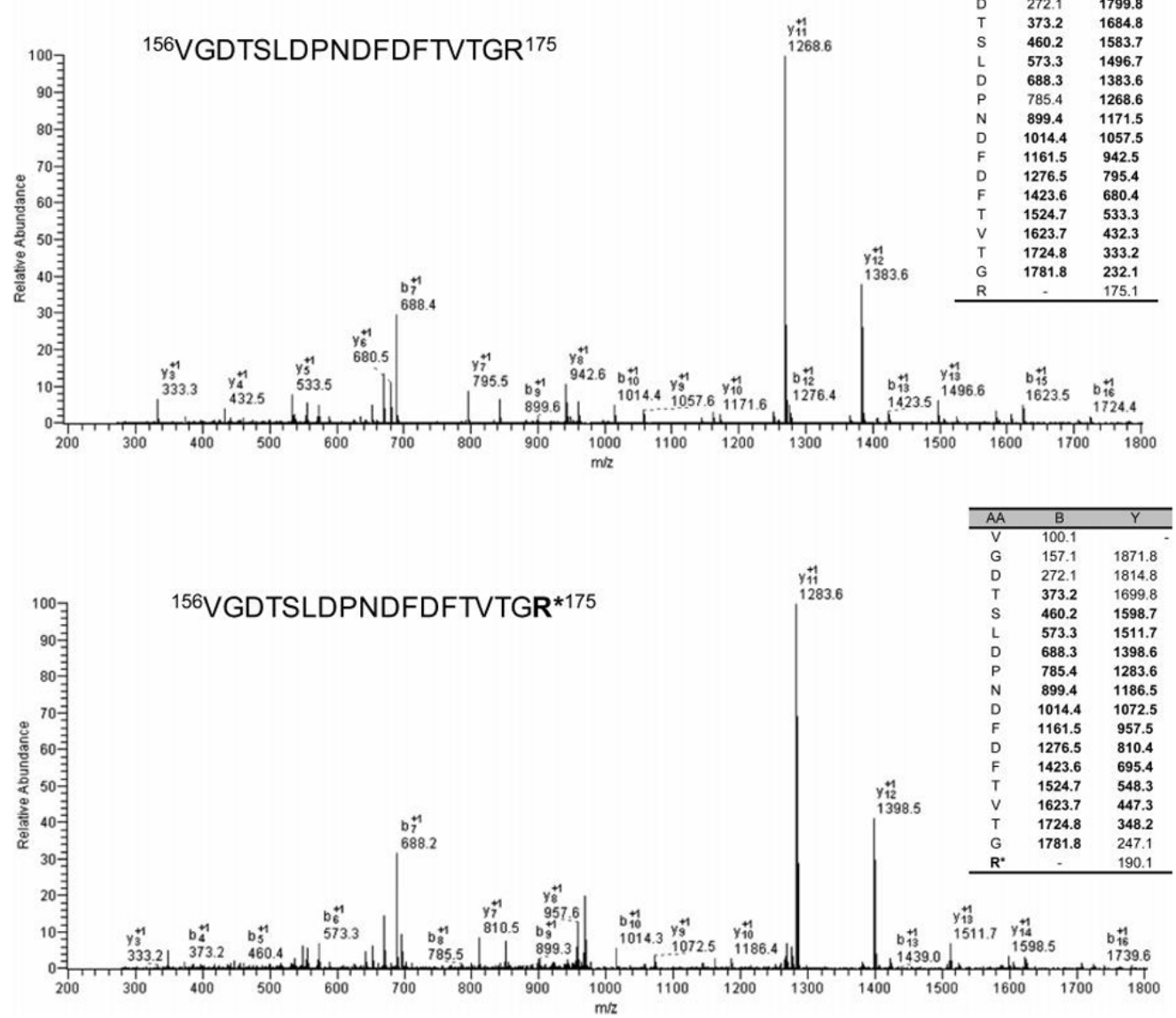

Figure 5.

MS/MS confirmation of in vivo labeling of a MeCP2 peptide containing Arginine with ${ }^{13} \mathrm{CH}_{3}$-Met. The same sample as in Figure 4 was analyzed and a methyl peptide was found to be labeled at $\mathrm{R}$ with an expected $15 \mathrm{Da}$ mass increase, demonstrating in vivo methylation at the R residue. MS/MS spectra of (A) the unmodified MeCP2 peptide ${ }^{156}$ VGDTSLDPNDFDFTVTGR ${ }^{175}$ and (B) its methylated counterpart. The ${ }^{13} \mathrm{CH}_{3^{-}}$ methylated $\mathrm{R} *$ is evidenced by y3-y14 ions with $15 \mathrm{Da}$ mass shifts. 


\section{Table 1}

Mono- and Dimethylated Amino Acid Residues Identified in p53, SMC3, MeCP2, and iNOs

\begin{tabular}{|c|c|c|}
\hline protein & peptide sequence & methylated AA residue \\
\hline \multirow[t]{8}{*}{ p53(gi:506435) } & ${ }^{7}$ DPSVEPPLSQETFS 20 & $\mathrm{E} 11 / \mathrm{E} 17(+14 \mathrm{Da})^{a}$ \\
\hline & ${ }^{49}$ DIEQWFTEDPGP ${ }^{60}$ & E51 (+14 Da) \\
\hline & ${ }^{102}$ TYQGSYGFR $^{110}$ & R110 (+14 Da) \\
\hline & ${ }^{111}{ }^{\text {LGFLHSGTAK }}{ }^{120}$ & H115 (+14 Da) \\
\hline & ${ }^{203}$ VEYLDDR $^{209}$ & E204/R209 (+14 Da) ${ }^{a}$ \\
\hline & ${ }^{208}$ DRNTFRHSVVVPYEPPEVGS 227 & $\mathrm{R} 209 / \mathrm{R} 213 / \mathrm{E} 221 / \mathrm{E} 224(+14 \mathrm{Da})^{a}$ \\
\hline & ${ }^{293}$ GEPHHELPPGSTK ${ }^{305}$ & E295 (+14 Da) \\
\hline & ${ }^{322}$ PLDGEYFTLQIR ${ }^{333}$ & $\mathrm{E} 326(+14 \mathrm{Da})$ \\
\hline \multirow[t]{12}{*}{ SMC3 (gi:4885399) } & ${ }^{62}$ LALLHEGTGPR $^{72}$ & $\mathrm{R} 72(+14 \mathrm{Da})$ \\
\hline & ${ }^{144}{ }^{I N Q M A T A P D S Q R ~}{ }^{155}$ & R155 (+14 Da) \\
\hline & ${ }^{222}$ ALEYTIYNQELNETR ${ }^{236}$ & R236 (+14 Da) \\
\hline & ${ }^{239}{ }^{2}$ DELSAK $^{245}$ & K245 (+14 Da) \\
\hline & ${ }^{265}$ DKMEDIER $^{272}$ & $\mathrm{R} 272(+14 \mathrm{Da})$ \\
\hline & ${ }^{311}$ DLQDELAGNSEQR $^{323}$ & R323 (+14 Da) \\
\hline & ${ }^{401}$ SLDQAINDK ${ }^{409}$ & K409 (+14 Da) \\
\hline & ${ }^{419}$ DLEDTEANKEK $^{429}$ & $\mathrm{~K} 427 / \mathrm{K} 429(+14 \mathrm{Da})^{a}$ \\
\hline & ${ }^{437}$ LDQDLNEVK $^{445}$ & K445 (+14 Da) \\
\hline & ${ }^{475}$ EENAEQQALAAK ${ }^{486}$ & K486 (+14 Da) \\
\hline & ${ }^{635} \mathrm{SMEVSTQLAR}^{644}$ & K644 (+14 Da) \\
\hline & ${ }^{986}$ ALDQFVNFSEQK ${ }^{997}$ & K997(+14 Da) \\
\hline \multirow[t]{5}{*}{ MeCP2(gi:4826830) } & ${ }^{257} \mathrm{AEADPQAIPK}^{266}$ & E258 (+14 Da) \\
\hline & ${ }^{295}$ SVQETVLPIK $^{304}$ & E298 (+14 Da) \\
\hline & ${ }^{436}$ TQPAVATAATAAEK ${ }^{449}$ & E448 (+14 Da) \\
\hline & ${ }^{201}{ }^{A A T S E G V Q V K R}{ }^{211}$ & $\mathrm{~K} 210(+28 \mathrm{Da})$ \\
\hline & ${ }^{116}$ SAGKYDVYLINPQGK ${ }^{130}$ & K119 (+28 Da) \\
\hline \multirow[t]{3}{*}{ iNOS (gi:6754872) } & ${ }^{408}{ }^{A V T E I N V A V L H S F Q K ~}{ }^{422}$ & K422 (+14 Da) \\
\hline & ${ }^{1031}$ VLFQVHTGYSR ${ }^{1041}$ & R1041 (+14 Da) \\
\hline & ${ }^{1105}$ LIQSPPEPLDLNR $^{1118}$ & E1110/R $1118(+14 \mathrm{Da})^{a}$ \\
\hline
\end{tabular}

${ }^{a}$ Either residue was methylated individually, but no dimethylation was ever observed on the same peptide. 